\title{
EFL Teachers' Identity (Re)Construction as Teachers of Intercultural Competence: A Language Socialization Approach
}

\section{Deniz Ortaçtepe}

To cite this article: Deniz Ortaçtepe (2015) EFL Teachers' Identity (Re)Construction as Teachers of Intercultural Competence: A Language Socialization Approach, Journal of Language, Identity \& Education, 14:2, 96-112, DOI: 10.1080/15348458.2015.1019785

To link to this article: http://dx.doi.org/10.1080/15348458.2015.1019785

曲 Published online: 13 May 2015.

Submit your article to this journal $₫$

Џ Article views: 735

Q View related articles $\sqsubset$

View Crossmark data ־

Citing articles: 4 View citing articles $\asymp$ 


\title{
EFL Teachers' Identity (Re)Construction as Teachers of Intercultural Competence: A Language Socialization Approach
}

\author{
Deniz Ortaçtepe \\ Bilkent University
}

\begin{abstract}
Adapting Norton's (2000) notion of investment as an analytical lens along with thematic analysis, this longitudinal/narrative inquiry explores how 2 EFL teachers' language socialization in the United States resulted in an identity (re)construction as teachers of intercultural competence. Baris and Serkan's language socialization in the United States was marked with 3 identity investments: as an experienced EFL teacher, as an L2 user, and as a burgeoning scholar. The findings highlighted that teacher identities are not unitary, fixed, or stable but dynamic, situated, multiple (e.g., Norton Peirce, 1995; Varghese, Morgan, Johnston, \& Johnson, 2005), and even sometimes blurred (e.g., Ochs, 1993).
\end{abstract}

Key words: language socialization, identity, intercultural competence

Compared to the widespread representations of language learner identities in the field of TESOL, language teacher identity is still a subject to be explored (e.g., Ha, 2008; Norton \& Toohey, 2011). Therefore, this study aims to explore the identity negotiation of 2 experienced language teachers who came to the United States to pursue graduate degrees. Several arguments contributed to the rationale for this study. First, the small body of empirical research on teacher identity dealt with the developmental processes that prospective teachers go through (Clarke, 2008); their imagined identities (Barkhuizen, 2009) and identity construction as novice teachers (Kanno \& Stuart, 2011; Liu \& Fisher, 2006; Tsui, 2007) as well as non-native English speaking teachers (Park, 2012); and the role of imagined communities on MA TESOL students' bilingual identities (Pavlenko, 2003).

Second, since the goal of foreign language learning is no longer limited to the acquisition of communicative competence, but requires language teachers to teach the target language with its cultural dimension (Sercu, 2006), there appears to be a need to explore how language teachers negotiate their identities as teachers of intercultural competence. Byram's (2003) notion of intercultural competence consists of several savoirs that relate to the attitudes (e.g., curiosity and openness), knowledge (e.g., discovery and interaction), skills (e.g., interpreting and relating), and cultural awareness (e.g., critical evaluation of another as well as one's own culture) that one

Correspondence should be sent to Deniz Ortaçtepe, Graduate School of Education, Bilkent University, Bilkent/ Ankara, Turkey. E-mail: deniz.ortactepe@bilkent.edu.tr 
needs to possess both in his or her own culture and in the target language (TL) culture. Magos and Simopoulos (2009) define intercultural competence as "the ability to deal with differences that derive from everyday communication" (p. 255). Hence, one of the ways to develop intercultural competence is through living or studying abroad, travelling, and meeting new people from different cultural backgrounds (Fleming, 2009). While there is abundant research on intercultural competence from the perspectives of language learners (e.g., Murphy-Lejeune, 2003; Roberts, 2003), the stories of language teachers who go abroad for professional development or a graduate degree remain untold. Hence, the use of language socialization as a conceptual framework is a novel way of looking at language teacher identity, especially for the "outer circle" English speakers (Kachru, 1992) who learn English as a foreign language (EFL). Thus, the present study, by responding to Varghese, Morgan, Johnston, and Johnson's (2005) call for multiple theoretical approaches to explore teacher identity, aims to explore how 2 experienced EFL teachers' language socialization experiences in the United States enabled them to (re)construct their identities as teachers of intercultural competence.

\section{LITERATURE REVIEW}

\section{Teacher Identity}

After the dominance of the prestigious status of the so-called native speaker, second language (L2) acquisition researchers have started to recognize teachers from a variety of backgrounds (Canagarajah, 2005; Davies, 2003; Holliday \& Aboshiha, 2009; Moussu, 2010; Moussu \& Llurda, 2008; Faez, 2011; Park, 2012). The discussion during the past 20 years on native speaker fallacy (Phillipson, 1992) revolves around the idea that the term native speaker is discriminative since the expanding nature of English has resulted in the rejection of home country status (Holliday \& Aboshiha, 2009). Cook's (1999) notion of L2 User, then, can be considered as a milestone, with its reconceptualization of so-called nonnative speakers as multicompetent, genuine L2 users rather than imitators of native speakers.

In the midst of this discussion, the issue of teacher identity plays a major role in describing the many identities adopted by these nonnative speaker teachers, who need to juggle at least 3 identities - L2 user, L2 learner, and L2 teacher-along with various sociocultural and political identities that are established in various institutional and interpersonal contexts (Armour, 2004; Duff \& Uchida, 1997). For instance, Western-trained Vietnamese teachers of English in Ha's (2008) study "experienced changes in their identities as a result of their exposure to a new context with different cultural and pedagogical practices, but they seemed to negotiate their identities on the basis of 'dominant' identities" (p. 181), which was the Vietnamese cultural, learner, and teacher identity. In Armour's (2004) study, Sarah, a Japanese language teacher in Australia, juggled various identities as an L2 user, learner, and teacher; her 3 L2-related identities represented fuzzy boundaries indicating the role of identity slippage. On the other hand, Pavlenko's (2003) study that examined the imagined professional and linguistic communities available to ESL/EFL teachers illustrated that the participants changed their levels of participation within their imagined communities, depending on the way they positioned themselves as community members of either native speakers or nonnative speakers. 


\section{Intercultural Communicative Competence}

A current issue that ties together teacher identity and the native speaker fallacy is intercultural communicative competence, an approach that questions native speaker competence as the ultimate goal of language learning and instead emphasizes the way language is used to negotiate positionings in various social contexts (Byram, 2003; Corbett, 2003). Relating intercultural approach to teacher identity, Sercu (2006) proposed the term foreign language and intercultural competence teacher (FL\&IC teacher) to refer to the language teachers' responsibilities to "teach intercultural communicative competence instead of communicative competence" (p. 56). By transforming Byram's (2003) conceptual savoirs into specific knowledge, skills, and attitudes, Sercu (2006) listed several qualities that an FL\&IC teacher should possess in order to promote intercultural competence (e.g., being familiar with the target language culture as well as one's own culture and being able to explain the similarities and differences between the 2 cultures).

According to Risager (2000), the development of teachers' intercultural competence demands a lifelong socialization process. In an earlier work exploring teachers' sociocultural identities through a language socialization approach, Duff and Uchida (1997) highlighted the importance of EFL teachers' roles, beliefs, and identities in shaping their teaching practices, especially in regard to integrating the target language culture into their classes. Their study revealed that EFL teachers' identities were shaped by "their personal histories, based on past educational, professional, and (cross-) cultural experiences" (p. 460). These findings illustrate the role of primary socialization in one's own culture, since this process shapes the values and conventions people adapt; and only when these values are questioned due to new socialization experiences will intercultural competence begin to evolve (Alred, Byram, \& Fleming, 2003). Thus, language socialization in the target culture plays a paramount role in developing teachers of intercultural competence in order to equip EFL teachers with the necessary sociocultural knowledge and pragmatic rules, as well as the skills to promote learners' acquisition of intercultural competence.

\section{Language Socialization}

Language socialization, a multidisciplinary field that has its roots in psychology, anthropology, linguistics, sociology, and education, combines language acquisition and socialization in such a way that "the process of acquiring language is embedded and constitutive of the process of becoming socialized to be a competent member of a social group" (Ochs \& Schieffelin, 2008, p. 5). Language socialization, besides being adapted to many different contexts such as family dinner time discourse (Blum-Kulka, 2008), schools (Baquedano-Lopez \& Kattan, 2008), and deaf communities (Erting \& Kuntze, 2008), is also employed as an umbrella term to explain the acquisition of certain discursive features within different social contexts. For instance, the acquisition of pragmatic knowledge was explained though pragmatic socialization (Li, 2000) while academic discourse socialization covered academic language and literacy (Duff, 2010). The term, conceptual socialization, was also proposed to refer to L2 learners' acquisition of social and linguistic skills within the target culture (Kecskes, 2002; Ortaçtepe, 2012).

While early research on language socialization aimed to understand how children become members of their own culture, recent research adapted language socialization to L2 acquisition, so as to examine both formal and informal contexts in which there is a more experienced person 
(e.g., language teacher) who helps a novice (e.g., language learner) "to gain expertise in the ways of the community" (Duff, 2008, p. xiv). In that sense, second language socialization studies examined L2 learners' language and social development in the target culture (Kanagy, 1999; Matsumura, 2001; Willett, 1995). These studies all agreed that schools and/or other educational settings are important sites for socialization in which language learners acquire communicative competence that spans their lifetime and experiences (Baquedano-Lopez \& Kattan, 2008).

Language socialization research has also dealt with more sociocultural issues such as exploring the identities, values, and practices that newcomers need to adopt in order to gain legitimate membership into a new community (Duff, 2008). According to Lantolf and Pavlenko (2001), an "individual's identity emerges out of the dialogic struggle between the learner and the community" (p. 149). Adams and Marshall (1996) describe the fundamental interconnectedness of the processes of identity construction and language socialization in the following way: "An individual's personal or social identity not only is shaped, in part, by the living systems around the individual but the individual's identity can shape and change the nature of these living systems" (p. 432). Given the intricate relationship between language socialization and identity, researchers mostly focused on language learner identity (Miller, 2003; Schecter \& Bayley, 2004; Talmy, 2008), while language teachers' identity is yet to be explored from a language socialization perspective. The next section will explain why further critical scrutiny of the impact of language socialization on teachers of intercultural competence would be helpful and timely in the context of the present study, Turkey.

\section{English Education in Turkey}

Turkey, as a foreign language context, provides few opportunities for language learners to use the target language for daily social interaction as well as to familiarize themselves with the target culture. ${ }^{1}$ Therefore, foreign language education in Turkey mostly relies on classroom instruction, which assigns teachers both the role of language teacher and cultural mediator. While the Turkish National Curriculum emphasizes the importance of target culture, both the national course books and the teacher education curriculum in foreign language teaching departments fail to provide prospective teachers and language learners with the knowledge, skills, and attitudes to be interculturally competent (Atay, 2005; Hatipoğlu, 2012). As Atay's (2005) study illustrates, not only is there a mismatch between the objectives of the national curriculum for foreign language teaching and the training the prospective teachers receive, but also the prospective teachers' perspectives on cultural enrichment are "far away from making Turkish learners interculturally sensitive" (p. 233). Hatipoğlu's (2012) study on teachers' attitudes toward teaching and learning TL culture concurs with Atay's (2005) in the sense that, although future language teachers agreed on the need to learn the culture of the language they are teaching, they did not seem to be familiar with the target culture, nor did they believe in the importance of teaching the target culture in their own classes. While the studies of Atay (2005) and Hatipoğlu (2012) provide insights into the role

\footnotetext{
${ }^{1}$ Since the English language curriculum in Turkey relies on the framework of English as a foreign language, references to the target culture include the American culture and British culture-i.e., the inner circle countries (Kachru, 1992), where English is spoken as the native language. However, in this study, the target culture refers to the American culture since the 2 participants were studying in the States at the time of the study.
} 
of culture in language teaching in Turkey, both researchers surveyed the prospective teachers' opinions rather than those of in-service teachers. Therefore, the present study aims to shed light on 2 experienced EFL teachers' identity (re)construction as teachers of intercultural competence by examining their language socialization processes during their graduate studies in the United States.

\section{METHOD}

This longitudinal, narrative inquiry explores the language socialization processes of Serkan and Baris (both pseudonyms), 2 experienced EFL teachers, who used to work in Turkey before coming to the United States for graduate study, and their identity negotiation as teachers of intercultural competence. By doing so, I aim to answer the following research question: How did 2 EFL teachers' language socialization processes in the United States enable them to (re)construct their identities as teachers of intercultural competence?

\section{Data Collection}

Language socialization, the theoretical framework of the study, has benefited the methodology of the study in several ways. To begin with, similar to the previous studies focusing on identity construction (Kanno, 2003; Norton, 2000; Polanyi, 1995; Tsui, 2007) as well as language socialization (Ochs, 1993; Ortaçtepe, 2013), this study adopted a narrative approach for 2 main reasons. First, narratives help individuals make sense of their lived experiences as well as themselves (Clandinin \& Connelly, 2000); second, narratives provide a rich source of data to explore language socialization (Pavlenko, 2008). Therefore, the participants' stories of language socialization were collected through 3 instruments to yield in-depth data: autobiographical narratives, journal entries, and interviews. It is also noteworthy to mention that narrative, in this study, is adopted as "both phenomenon and method" (Connelly \& Clandinin, 1990, p. 2) in the sense that it refers to participants' language socialization stories as depicted in the 3 data sources as well as the way the data were analyzed in relation to the participants' narrated identities.

Data triangulation through multiple data sources enabled the researcher, not only to avoid vulnerability to errors that might derive from using only 1 data source, but also to provide "crossdata validity checks" by identifying the general themes and patterns across participants as well as data sources (Patton, 2002, p. 248). It is noteworthy to mention that the goal with triangulation was not to reach the same results across all data sources but to understand inconsistencies as well as different nuances so as to gain deeper insights into the phenomenon under study.

Based on the framework of language socialization, this study also relied on a longitudinal design to investigate the language socialization trajectories of the participants and trace how their multiple identities were transformed across time and space (Hornberger, 2007). In that sense, the data collection procedure consisted of 3 phases: The first data collection phase took place during the participants' second month in the United States, October 2009, while the last one occurred at the end of the academic year in June 2010. Between each data collection phase, there were followup email exchanges between the researcher and the participants; hence, the data collection was a continuous process rather than one that consisted of 3 discrete phases. 
TABLE 1

Data Collection Procedure

\begin{tabular}{|c|c|c|}
\hline $\begin{array}{l}1^{\text {st }} \text { phase: } \text { October } 2009 \\
\text { Autobiographical narratives }\end{array}$ & $\begin{array}{c}2^{\text {nd }} \text { phase: January } 2010 \\
\text { Journal Entries }\end{array}$ & $\begin{array}{l}3^{\text {rd }} \text { phase: June } 2010 \\
\text { Journal Entries }\end{array}$ \\
\hline $\begin{array}{l}\text { Interview: Past } \\
\text { - the participants' aspirations, } \\
\text { history, and life circumstances }\end{array}$ & $\begin{array}{l}\text { Interview: Present } \\
\text { - what they are doing in the U.S., } \\
\text { what roles they have taken, who } \\
\text { they have had contact with, in } \\
\text { what social situations they are } \\
\text { involved }\end{array}$ & $\begin{array}{l}\text { Interview: Future } \\
\text { - future expectations from } \\
\text { their lives in the U.S. as well } \\
\text { as an overall discussion on } \\
\text { what has been discussed and } \\
\text { left out in their stories }\end{array}$ \\
\hline
\end{tabular}

The interviews were based on Seidman's (2006) 3-part-interview design, which comprised the participants' past, present, and future (see Table 1). Seidman's (2006) design fit well with the narrative inquiry adapted in this study since "narrative phenomena are not seen as existing in the here and now but, rather, are seen as flowing out of the past and into the future" (Xu \& Connelly, 2009 , p. 224). In the journal entries, the participants were provided prompts that would enable them to focus on their social and academic lives as well as language learning/using experiences in the United States.

\section{Data Analysis}

Data analysis consisted of several steps. First, all interviews were audiotaped and then transcribed verbatim for data analysis. Then, I analyzed all qualitative data coming from autobiographies, journal entries, and interview transcripts according to Boyatzis's (1998) thematic analysis, which provided a preliminary analysis of the recurrent themes, patterns, and categories. After reviewing the data coming from the aforementioned data sources multiple times throughout the project, I identified the salient themes-first on paper and then by using NVivo, a software program for qualitative data analysis. Some of the themes that emerged at this stage were language teaching in Turkey, language use in the United States, doctoral studies, social networks, and so forth.

While thematic analysis is a good start to identify recurrent motifs in the participants' stories, its main disadvantage is that without a conceptual framework or a construct that ties all the themes together, the researcher might be left with a laundry list (Pavlenko, 2007). Therefore, in the second step of the analysis, I adopted Norton's (2000) notion of investment as an analytical lens to interpret the emerged themes in relation to this conceptual construct. The notion of investment, which aims to capture the constructed relationship between the language learner and the social world, emphasizes that "if learners invest in L2, they do so with the understanding that they will acquire a wider range of symbolic and material resources, which will in turn increase the value of their cultural capital" (Norton Peirce, 1995, p. 3). Hence, not only are people's behaviors and choices triggered by their investment, but their investment is strictly related to their imagined communities, in which they see themselves as prospective members (Norton, 2001). In that sense, the notion of investment as a conceptual construct enabled me to interpret the themes that emerged from thematic analysis so as to understand the participants' many identity investments to become socialized in their communities. Some of the questions asked at this stage 
to relate the notion of investment with the emerged themes are, How is their identity investment as doctoral students related to their current social networks? and, How is their identity investment as language teachers influenced by the way English language is used in the United States?

\section{The Role of the Researcher}

According to Patton (2002), "Because the researcher is the instrument in qualitative inquiry, a qualitative report should include some information about the researcher" (p. 566). The participants and I, the researcher, shared a similar background: I was also a Turkish student pursuing a graduate degree in the United States, but more important than that, I too received my BA degree in an ELT department and worked as a foreign language teacher in Turkey. With this similar background, I was able to develop rapport with the participants and create trust and a safe context in which they could candidly share their stories. The disadvantage of having similar experiences is that the predispositions I developed as a researcher could have influenced the data collection procedure. I tried to minimize the researcher bias through triangulation with multiple data sources, as well as adapting the stance of empathic neutrality in which I was caring about and interested in the participants but "neutral about the content of what they reveal" (Patton, 2002, p. 569). In other words, this empathic neutrality enabled me to establish trustworthiness in the data collection and analysis procedures through which I aimed to reflect the participants' own voices rather than reflecting my own dispositions as someone who shared the same background.

\section{FINDINGS}

\section{Language Socialization and Identity Investments}

In this section, I will be discussing how Baris and Serkan's language socialization trajectories could be described in terms of the 3 identity investments they had: an experienced EFL teacher, an L2 user, and a doctoral student.

Baris. When Baris first started learning in English in the sixth grade, his perception of the language consisted of "[it was] just a course like geography or science." The foreign language context in Turkey led him to learn English just to receive a high grade on the tests. Not being able to experience the English language as a tool for communication, Baris never thought, "OK, I'm learning English so I can go to the store now and buy something by using this language." Even during his high school years when he was studying English intensively, the focus was on grammar and vocabulary, giving him no opportunities to actually use this emerging knowledge in social interactions. His struggle to speak the language continued during his college years when he was studying to be an English teacher. After graduation, Baris started working as an English instructor at a Turkish university. There were teachers from all around the world, including the United Kingdom, the United States, Nigeria, and even Russia. Baris had finally found the opportunity to speak English in social interactions with his colleagues.

Baris decided to pursue a doctoral degree in the United States after completing his MA degree in the department of English language and literature. Baris stated, 
I believed that as an English instructor, I had to live for a while in an English-speaking country so that I could better teach English to my students in Turkey. I wanted to learn about different perspectives in education; to experience a different milieu; to meet people from different nations and cultures; to participate in the lectures of eminent scholars; and to attend prestigious conferences on ELT; and to present a paper if possible. (Interview 1)

Baris's reasons for pursuing a doctoral degree in the United States underline the importance of his identity investment both as a doctoral student and an EFL teacher. He was in the States not only as a doctoral student but also as someone who had been teaching the language of a country that he had never visited before until then. During the second interview, Baris noted, "We are not teaching the language in Turkey, but some parts of it, such as vocabulary . . . if you tell people that you will teach them the language instead, they will ask you, 'OK what am I going to do with it?" Duly noting these problems in language teaching in Turkey, Baris started his doctoral studies in the States, a journey that would shape his identity both as a teacher and a student.

Baris's experiences in the United States could be described as academic discourse socialization through which he learned how to participate and be a legitimate member of the academic community in which his identity as a scholar was invested in. Duff (2010) explains academic discourse socialization as "a dynamic, socially situated process that in contemporary contexts is often multimodal, multilingual, and highly intertextual as well" (p. 169). The downside of Baris's academic discourse socialization, however, was his overemphasis on academic studies, which prevented his opportunities to meet other people or to see new places. His "educational life [was] controlling his social life" (second journal entries), Baris thought it was really difficult for him to have time for other things when he was a student. For this reason, his imagined communities would not only bring him an academic career but also opportunities for socialization. Thus, Baris's academic discourse socialization entails, not only his identity negotiation as a budding scholar to become a member of the academia, but also his socialization processes in the United States:

I feel like a visiting team in soccer . . . not having the home field advantage . . As if the people who live here own this country, not us; maybe that's why I feel distant to Americans and closer to the other international people . . . because we are equal in terms of status. (Interview 1)

Baris's investment as a scholar and his socialization processes are closely related since he believes that working in the United States and having colleagues instead of classmates would create a different social context for him, one in which he could feel less like a "foreigner." In such a context, he would not only engage in interactions with American people but also learn more about them in regard to their social interactions; for example, the topics they talk about or insights into their family relations. In short, anything that extends beyond the "academic talk" that he shares with his classmates.

As mentioned earlier, Baris's language socialization in the United States was influenced not only by his investment as a doctoral student but also by his identities as an L2 user and teacher. Baris stated,

When I was working as an English teacher, I believed that I was not doing a bad job teaching English. But after coming here, it feels like I am learning English all over again. For example, there are things I never thought about in Turkey; here when I talk to people I go, "How can I say this?" In Turkey, I 
just taught whatever was in the textbook; I never needed to use the language to engage in interactions. (Interview 2)

Baris's identity as an L2 user and teacher has shaped his interactions in English in such a way that he not only monitored his English, but he also made constant comparisons in regard to the English he used to teach in Turkey and the English that is spoken in the United States. His socialization in the United States enabled Baris to realize that English education in Turkey is heavily based on grammar and reading. The language used in daily interactions revealed the most differences between the English he taught and the English that was actually used in the United States. To illustrate this discrepancy, Baris gave the following example:

\footnotetext{
"Aren't you?" to give a positive response to a negative question, you need to use "no." The professor asked me something in class with "aren't you ...." and I said "yes." He did not get it so he asked again. Then it occurred to me ... pragmatics ... I felt bad because I thought I have been teaching English but I didn't know this. (Interview 1)
}

The United States presented Baris with a new way of using the English language, which was starkly different from the English Baris used for teaching in his home country. These differences, he observed, made Baris ponder upon the problems of teaching English in Turkey. Noticing the differences between the "English-taught" and the "English-used" not only led to queries in language usage but also helped Baris to develop hypotheses about what needs to be changed in Turkish curriculum as well as in his own teaching practices, to teach English more effectively.

Serkan. Serkan began learning English at an Anatolian High School where he attended a year of hazirlik (intensive English preparatory year) after the fifth grade. While hazirlik included 28 hours of instruction with enhanced classroom interactions in English every week, when he moved to Germany with his parents, Serkan realized that "the English I learned in Turkey was useless and helpless." After studying at an international school for 5 years in Germany, he was really fluent and felt at ease in expressing his ideas and feelings in English. However, his proficiency in English started to decline slowly after he returned to Turkey to pursue his BA degree in English language teaching. During the first interview, Serkan noted: "In college, we spoke English but it was more formulaic in the sense that it was limited to class discussions. The social language was impeded because I didn't use it in social contexts." Immediately after receiving his BA degree, Serkan started working as an English instructor at a large university. Within a few years, Serkan began pursuing his MA degree in TESOL at a Turkish university, but all his professors were native speakers, thereby, providing him with a context for academic socialization in English.

Serkan's journey to the United States started with his application for a world famous scholarship, which would enable him not only to practice the English language but also to learn about the culture of the language that he had been teaching for many years without really being in an English-speaking country. His problem in communicating with others was not related to the linguistic aspects of the language but rested on "cultural differences." The crux of the matter, he pointed out in the second journal entries, is that "you express yourself in a different way than they are used to, which leads to misunderstandings." These kinds of cultural differences concerning language use are what drove Serkan to the States. Unlike Baris who was a full-time doctoral student in the United States, Serkan was enrolled as a doctoral student in a Turkish university 
and studied in the United States for only 1 year. Yet, he pursued a similar investment as Baris since he wanted to work in the United States after graduation. However, faced with academic challenges (e.g., lack of academicians with whom he could exchange ideas or collaborate in the future), Serkan spent a year away from academic ventures, which led him to focus more on his social life.

According to Watson-Gegeo (2004), "People learn language(s) in social, cultural and political contexts that constrain the linguistic forms they hear and use and also mark social significance of these forms in various ways" (p. 340). Serkan experienced a campus-based life in which his colleagues were also his friends with whom he attended campus-based social events. This type of social interaction impacted his language development, leading Serkan to engage in specific discourses (e.g., restaurant and grocery shopping) that reoccur in daily living. Hence, Serkan's trajectory in the United States could be described as discourse socialization, a subpractice of language socialization that Duff (2010) describes as a dynamic, socially situated process emphasizing social practices and interaction. Serkan noted,

My weakness is, I haven't been able to involve in new contexts and observe the different ways the language is used. My social encounters are limited to basic things, such as restaurant, placing an order, grocery shopping or hanging out with college kids. (Interview 3)

That is, Serkan was surrounded by the same types of interactions in his social and academic contexts due to his limited social networks.

Despite being a very proficient user of English as well as an experienced EFL teacher, Serkan struggled during his first months in the United States, even with simple social encounters such as ordering food at a restaurant. Similar to Baris, Serkan's language-teaching background provided him with metalinguistic awareness that enabled him to monitor his language skills. Serkan stated,

I could understand what the waitress was saying but I was not familiar with that discourse. In Turkey, it's totally different . . . You can call the waiter "abi" (brother). Here, the waiters are well trained, they start with hello, welcome, and every now and then check on you to see how you are doing. In Turkey, the waiters just ask you whether you want to have tea once you finish eating. (Interview 3)

During his social interactions in the United States, Serkan recognized his strengths and weaknesses in terms of language and noticed that his problem in communicating with others was not related to grammar or the linguistic aspects of the English language but rested on cultural differences. According to Serkan, the "book English" taught in Turkey, in which "the formal aspects of the language tense and grammar dominated, with great emphasis on slight differences such as will vs. be going to" was the main reason why he sounded different from American speakers. Thus, Serkan's language socialization required the dismissal of the formal language habits established in instructional discourse in Turkey and instead embracing the use of conversational discourse for daily interactions. Serkan confided that

I don't speak like them, but at least by using the phrases they use, I can establish a group membership, which tells them "I am one of you." By speaking in a similar way to them, you become like one of them; they don't see you as a foreigner anymore. (Interview 2)

His insights illustrate that the English language presented in textbooks assists language learners to function in the target language, but does not provide access to native speakers' preferences in ways of saying things that could warrant group membership. Hence, Serkan believed that 
he could align within social groups by using the appropriate expressions in specific discourses. In that sense, the social, cultural, and political dimensions of Serkan's surroundings constructed the linguistic and pragmatic input that he was exposed to during his 1-year study abroad, hence shaping his discourse socialization.

\section{Baris and Serkan as Teachers of Intercultural Competence}

Although both Baris and Serkan had identity investments as burgeoning scholars in academic communities, the differences between the situated practices they engaged in within their social contexts led to different socialization processes: academic discourse socialization and discourse socialization, respectively. These 2 socially and temporally situated subpractices of language socialization led to personal transformations in their identity as teachers of intercultural competence, thus revealing a new identity investment that Baris and Serkan took on to reflect upon their teaching practices in their home country.

According to Sercu (2006), one of the characteristics of teachers of intercultural competence is that they should be able to "help pupils relate their own culture to foreign cultures, to compare cultures and to empathize with foreign cultures' points of view" (p. 58). Hence, Baris and Serkan's readiness to experience different socialization practices in the culture of the target language as well as the complex nature of identity investments led to changes in their identities as teachers of intercultural competence. Baris noted,

For instance, the professor sends me an e-mail and says, "Meet me Friday," not "on" Friday. Last week, after a meeting with a professor, he sent me an email to say that he had my book and I had his and he used: we traded books. If someone asked me, I would probably say we switched or exchanged . . . no way I could think of "we traded books." (Interview 2)

Baris and Serkan's identities as teachers of intercultural competence also enabled them to reflect on their current and future language-and-culture teaching practice. Their 1-year language socialization in the United States shaped not only the way they communicated in English but also the way that they would teach the language upon their return to Turkey. Both participants indicated that the foreign language context in Turkey, along with the emphasis on high-stakes tests, pose grave problems to English language teaching in Turkey. Baris said,

The English courses in Turkey teach for the test, we do not teach the language, or how to communicate in that language but vocabulary and grammar, whatever is relevant for those tests. (Journal 1)

As these comments indicate, through their language socialization experiences, Baris and Serkan became aware that language learners need more than linguistic competence; they also need pragmatic and discourse competencies in order to be able to interact successfully in intercultural contexts. Serkan commented,

We teach certain structures but not how they are used in specific contexts. The best example for this is, "How are you?" If you ask someone this question, they would say "Fine thanks and you?" but here you see people say "How is it going?" and the other person responds with the same question, "How is it going" and walks by. You can't find this exchange in coursebooks. (Interview 2) 
Gaining insights into the goals for language teaching as well as the factors influencing decisionmaking processes in language-teaching institutions are also the features of becoming a teacher of intercultural competence (e.g., Larzen-Ostermark, 2008). Baris and Serkan both indicated that their teaching practices in Turkey would benefit from their language socialization in the United States, though the institutional and curricular demands in Turkey would still restrict their classroom practices. Baris indicated that

The curriculum and using 1 particular textbook would still limit me but I would definitely make some changes in my teaching. I would emphasize that, "OK, you are learning English grammar here, but when you go abroad, it will not be helpful at all. You need to learn a lot to communicate in English." (Interview 3)

According to Corbett (2003), an intercultural approach to invoke intercultural competence within language classrooms should trigger "the realization that the language class is part of a larger exploration of everyday cultural practices, at home and abroad" (p. 211). Thus, teachers of intercultural competence should be able to understand the influence of culture on communication and hence learn to mediate between the 2 cultures (Sercu, 2006). Serkan's insights illustrate how his teaching would revolve around certain target-language-specific discourses so as to explain to students the communicative functions of the language. Serkan said,

For example, when teaching the topic "food," instead of starting the conversation with "Hi, how can I help you?" I can tell my students that the discourse starts with "how many people" and follows a multi-step process with first bringing water, then the menu, and 10 minutes later the waitress coming to get your order. (Interview 3)

Baris and Serkan's comments on the challenges that foreign-language teachers in Turkey face resonate with Sercu's (2006) study, which revealed that the participating teachers from 7 European countries perceived intercultural awareness as being "an important proposal for innovation" yet "peripheral to the commonly accepted linguistic goals of foreign language education" (p. 68). Turkey, then, can be considered as one of those countries with teachers who want to move forward in developing learners' intercultural competence through their teaching practices, yet are hindered by institutional circumstances and curricular restrictions.

\section{DISCUSSION AND CONCLUSION}

The aim of this longitudinal, narrative inquiry was to explore how the language socialization processes of Serkan and Baris enabled them to (re)construct their identity as teachers of intercultural competence. The findings revealed that the different situational practices Baris and Serkan engaged in within particular social contexts led to different subpractices of language socialization-namely, academic discourse socialization for Baris and discourse socialization for Serkan. Overall, their language socialization in the United States was marked with 3 identity investments: (1) an experienced EFL teacher, (2) an L2 user, and (3) a burgeoning scholar. The stories of Baris and Serkan concurred with the sociocultural, post-modernist views of identity in the sense that their identities were dynamic, dialogic, situated, and multiple (Duff \& Uchida, 1997; Faez, 2011; Lantolf \& Pavlenko, 2001; Norton, 2000). Similar to many language teachers who sought to reconcile their various identities (Armour, 2004; Ha, 2008), Baris and Serkan's 
main identity investment as burgeoning scholars blended in with their identities as L2 users and teachers, as a result of their language socialization experiences in the United States. This finding echoes Armour's (2004) study, which pointed out that "learner-user and learner-teacher are both the two sides of the same coin" (p. 120). Accordingly, Baris and Serkan's trajectories in the United States not only presented an opportunity to earn a graduate degree (identity investment as a scholar) but also provided them with the context in which they could relate their own teaching as well as the teaching practices in Turkey to their lives in the United States (identity investment as an English teacher).

The participants' various identity investments were not in conflict but compatible with blurred boundaries (Ochs, 1993). For Baris, his identity investments as a doctoral student and a language teacher were blended in such a way that he was seeking solutions to the problems he observed as a language teacher through his doctoral studies. In a similar way, Serkan, during his social encounters, was drawing from both his scholarly identity and his identity as a language user. For both Baris and Serkan, their L2 user and teacher identities were interwoven in such a way that they would both feel bad when there was a miscommunication or a word/phrase that they did not know because they felt the need to know that word/phrase, or to express themselves fluently. While a major hurdle in gaining an understanding of teacher identity is resolving its definition, this aspect of blurred identities supports that EFL teachers and learners bring to the classroom not static, deterministic identities but complex and multifaceted ones that are co-constructed across time and space (Norton, 1997).

Baris and Serkan's blurred identities seem to contradict the findings of Pavlenko's (2003) study, which revealed that EFL teachers who had been teaching English in their home country expressed feelings of incompetency in terms of their language skills when they came to study in the United States and that their identities shifted from teachers to students. Pavlenko (2003) explained this finding in the following way: "If one cannot join a native speaker community, one has no choice but to adopt one of the two remaining identity options offered by the dominant discourse of native-speakerness: 'non-native speaker' or 'L2 learner'” (p. 259). However, in the present study, it was Baris and Serkan's socialization processes that enabled them to reconcile the many identities they possessed and, thus, take on a new identity as teachers of intercultural competence. Hence, Baris and Serkan's various identities also indicated that identity negotiation is context dependent and framed by social, political, and cultural discourses (Duff \& Uchida, 1997; Varghese et al., 2005).

The findings also revealed that Baris and Serkan's move towards becoming teachers of intercultural competence offered them a privileged understanding of the weaknesses of English language teaching in Turkey. The numerous examples Baris and Serkan provided in regard to the challenges of ELT in Turkey bore striking similarities to the findings of Atay (2005) and Hatipoğlu (2012), who demonstrated the gap between teachers' beliefs and their practices of integrating culture into language classroom. Overall, the insights of Baris and Serkan not only illustrated the overemphasis on the structural aspects and "teaching to test" approach in Turkey, but also highlighted their preference for a more intercultural approach to make language use more authentic and true to real life. Those contextual and institutional restrictions in Turkey can be explained by Duff and Uchida (1997), who state that "the cultures manifested and constructed in each classroom represented many elements, created by teachers, students, and others and shaped to a large extent by other factors, such as institutional goals and course textbooks" (p. 479). Hence, considering Turkey's candidacy to membership in the European Union, as well 
as its geographical and political position as a secular country located between Europe and Asia, the curriculum for language teaching should pay more attention to the current trends in language teaching and employ an intercultural approach by integrating the cultural and linguistic aspects of language learning. Similarly, foreign-language teachers should be granted the opportunity "to learn in an intercultural and international environment" (Sercu, 2006, p. 56) through experiential learning activities, exchange programs as well as school trips that would provide them with the knowledge, skills, and attitudes to become teachers of intercultural competence.

The findings of the study have also confirmed that the term native speaker is obscured and not applicable anymore given the unclear nature of linguistic boundaries and increasingly globalized, multilingual societies (Canagarajah, 2005; Davies, 2003). While Baris and Serkan did each perceive themselves as both L2 users and teachers in the United States, they never indicated any feelings of inferiority as nonnative-English-speaking EFL teachers. Instead, they considered their language socialization trajectories in the United States as an opportunity to reframe their teaching skills as teachers of intercultural competence. Thus, their stories call attention to the role of nonnative-speaker teachers who could navigate between the home and target culture so as to invoke intercultural competence in language classrooms (Corbett, 2003).

The findings of the study concur with Kanno and Stuart's (2011) assertion that there is a "need to include a deeper understanding of L2 teacher identity development in the knowledge base of L2 teacher education" (p. 236). However, as the present study's findings suggest, such understanding should not be limited to novice teachers and preservice education programs, but expand to experienced teachers who should seize every opportunity to enhance their knowledge and skills through professional development programs. Since teachers' professional identities are closely linked to their teaching practice as well as professional development (Duff \& Uchida, 1997; Tsui, 2007; Varghese et al., 2005), both professional development programs and teacher educators should perceive in-service or future teachers as human agents who are struggling to negotiate their various identities rather than as "technicians who needed merely to 'apply' the right methodology in order for the learners to acquire the target language" (Varghese et al., 2005, p. 22). An ethnographic case study exploring teachers' identity in relation to the way they integrate the practices, referents, and processes of the target culture would reveal great insights into the extent to which intercultural communication is forged, especially in foreign-language classrooms where the teacher is usually the only cultural mediator socializing language learners into the linguistic and cultural practices of the target language. One of the limitations of this study is that the issue of intercultural competence was approached in relation to the interaction between the participants and the target culture without focusing on the possible changes to the participants' perceptions of their own culture. Further studies can adopt a more retrospective approach when exploring the influence of second-language socialization on one' own cultural beliefs and attitudes, so as to better situate the bidirectional exchange of one's own culture and target cultures.

\section{REFERENCES}

Adams, G. R., \& Marshall, S. K. (1996). A developmental social psychology of identity: Understanding the person-incontext. Journal of Adolescence, 19, 429-442.

Alred, G., Byram, M., \& Fleming, M. (Eds.). (2003). Intercultural experience and education. Clevedon, UK: Multilingual Matters. 
Armour, W. S. (2004). Becoming a Japanese language learner, user, and teacher: Revelations from life history research. Journal of Language, Identity, and Education, 3(2), 101-125.

Atay, D. (2005). Reflections on the cultural dimension of language teaching. Language and Intercultural Communication, 5(3\&4), 222-236.

Baquedano-Lopez, P., \& Kattan, S. (2008). Language socialization in schools. In P. A. Duff \& N. H. Hornberger (Eds.), Encyclopedia of language and education (2nd ed., Vol. 8: Language Socialization (pp. 161-174). NY: Springer.

Barkhuizen, G. (2009). An extended positioning analysis of a pre-service teacher's better life small story. Applied Linguistics, 31(2), 282-300.

Blum-Kulka, S. (2008). Language socialization and family dinnertime discourse. In P. A. Duff \& N. H. Hornberger (Eds.), Encyclopedia of language and education (2nd ed., Vol. 8: Language Socialization (pp. 87-100). NY: Springer.

Boyatzis, R. E. (1998). Transforming qualitative information: Thematic analysis and code development. USA: Sage.

Byram, M. (2003). On being 'bicultural' and 'intercultural.' In G. Alred, M. Byram \& M. Fleming (Eds.), Intercultural experience and education (pp. 50-67). UK: Cromwell.

Canagarajah, A. S. (Ed.). (2005). Reclaiming the local in language policy and practice. Mahwah, NJ: Erlbaum.

Clandinin, D. J., \& Connelly, F. M. (2000). Narrative inquiry: Experience and story in qualitative research. San Francisco: Jossey-Bass.

Clarke, M. (2008). Language teacher identities: Co-constructing discourse and community. Great Britain: Multilingual Matters.

Connelly, F. M., \& Clandinin, D. J. (1990). Stories of experience and narrative inquiry. Educational Researcher, 19(5), $2-14$.

Cook, V. (1999). Going beyond the native speaker in language teaching. TESOL Quarterly, 33(2), 185-209.

Corbett, J. (2003). An intercultural approach to English language teaching. Great Britain: Multilingual Matters.

Davies, A. (2003). The native speaker: Myth and reality. England: Multilingual Matters.

Duff, P. A. (2008). Introduction to Volume 8: Language socialization. In P. A. Duff \& N. H. Hornberger (Eds.), Encyclopedia of language and education (2nd ed., Vol. 8: Language Socialization (pp. xiii-xx). Boston, MA: Springer.

Duff, P. A. (2010). Language socialization into academic discourse communities. Annual Review of Applied Linguistics, 30, 169-192.

Duff, P. A., \& Uchida, Y. (1997). The negotiation of teachers' sociocultural identities and practices in postsecondary EFL classrooms. TESOL Quarterly, 31(3), 451-486.

Erting, C. J., \& Kuntze, M. (2008). Language socialization in deaf communities. In P. A. Duff \& N. H. Hornberger (Eds.), Encyclopedia of language and education (2nd ed., Vol. 8: Language Socialization (pp. 287-300). Boston, MA: Springer.

Faez, F. (2011). Reconceptualizing the native/nonnative speaker dichotomy. Journal of Language, Identity, \& Education, 10(4), 231-249.

Fleming, M. (2009). Introduction. In A. Feng, M. Byram, \& M. Fleming (Eds.), Becoming interculturally competent through education and training (pp. 1-15). Bristol, UK: Multilingual Matters.

Ha, P. L. (2008). Teaching English as an international language: Identity, resistance and negotiation. Clevedon, UK: Multilingual Matters.

Hatipoğlu, Ç. (2012). British culture in the eyes of future English language teachers in Turkey. In Y. Bayyurt \& Y. Çetinkaya (Eds.), Research perspectives on teaching and learning English in Turkey. Hamburg, Germany: Peter Lang.

Holliday, A., \& Aboshiha, P. (2009). The denial of ideology in perceptions of "nonnative speaker" teachers. TESOL Quarterly, 43(4), 669-689.

Hornberger, N. H. (2007). Biliteracy, transnationalism, multimodality, and identity: Trajectories across time and space. Linguistics and Education, 18, 325-334.

Kachru, B. B. (1992). The other tongue: English across cultures (2nd ed.). Urban: University of Illinois.

Kanagy, R. (1999). Interactional routines as a mechanism for L2 acquisition and socialization in an immersion context. Journal of Pragmatics, 31, 1467-1492.

Kanno, Y. (2003). Negotiating bilingual and bicultural identities: Japanese returnees betwixt two worlds. Mahwah, NJ: Lawrence Erlbaum.

Kanno, Y., \& Stuart, C. (2011). Learning to become a second language teacher: Identities-in-practice. Modern Language Journal, 95(2), 236-252.

Kecskes, I. (2002). Situation-bound utterances in L1 and L2. Berlin, Germany: Mouton de Gruyter. 
Lantolf, J. P., \& Pavlenko, A. (2001). (S)econd (L)anguage (A)ctivity theory: Understanding second language learners as people. In M. Breen (Ed.), Learner contributions to language learning: New directions in research (pp. 141-159). Singapore: Longman.

Larzen-Ostermark, E. (2008). The intercultural dimension in EFL-teaching: A study of conceptions among FinlandSwedish comprehensive school teachers. Scandinavian Journal of Educational Research, 52(5), 527-547.

$\mathrm{Li}, \mathrm{D}$. (2000). The pragmatics of making requests in the L2 workplace: A case study of language socialization. Canadian Modern Language Review, 57(1), 58-87.

Liu, Y., \& Fisher, L. (2006). The development patterns of modern foreign language student teachers' conceptions of self and their explanations about change: Three cases. Teacher Development, 10, 343-360.

Magos, K., \& Simopoulos, G. (2009). "Do you know Naomi?” Researching the intercultural competence of teachers who teach Greek as a second language in immigrant classes. Intercultural Education, 20(3), 255-265.

Matsumura, S. (2001). Learning the rules for offering advice: A quantitative approach to second language socialization. Language Learning, 51(4), 635-679.

Miller, J. (2003). Audible difference: ESL and social identity in schools. Clevedon, UK: Cromwell Press.

Moussu, L. (2010). Influence of teacher-contact time and other variables on ESL students' attitudes towards native-and nonnative-English-speaking teachers. TESOL Quarterly, 44(4), 746-768.

Moussu, L., \& Llurda, E. (2008). Non-native English-speaking English language teachers: History and research. Language Teaching, 41, 315-348.

Murphy-Lejeune, E. (2003). An experience of interculturality: Student travellers abroad. In G. Alred, M. Byram, \& M. Fleming (Eds.), Intercultural experience and education (pp. 101-113). Clevedon, UK: Multilingual Matters.

Norton, B. (1997). Language, identity, and the ownership of English. TESOL Quarterly, 31(3), 409-429.

Norton, B. (2000). Identity and language learning: Gender, ethnicity, and educational change. Harlow, UK: Pearson Education.

Norton, B. (2001). Non-participation, imagined communities, and the language classroom. In M. Breen (Ed.), Learner contributions to language learning: New directions in research (pp. 159-171). Harlow, UK: Pearson Education.

Norton, B., \& Toohey, K. (2011). Identity, language learning, and social change. Language Teaching, 44(4), 412-446.

Norton Peirce, B. (1995). Social identity, investment, and language learning. TESOL Quarterly, 29(1), 9-31.

Ochs, E. (1993). Constructing social identity: A language socialization perspective. Research on Language and Social Interaction, 26(3), 287-306.

Ochs, E., \& Schieffelin, B. B. (2008). Language socialization: An historical overview. In P. A. Duff \& N. H. Hornberger (Eds.), Encyclopedia of language and education (2nd ed., Vol. 8, Language socialization (pp. 3-16). Boston, MA: Springer.

Ortaçtepe, D. (2012). The development of conceptual socialization in international students: A language socialization perspective on conceptual fluency and social identity. Newcastle upon Tyne, UK: Cambridge Scholarly.

Ortaçtepe, D. (2013). "This is called free falling theory not culture shock": A narrative inquiry on L2 socialization. Journal of Language, Identity, and Education, 12(4), 215-229.

Park, G. (2012). "I am never afraid of being recognized as an NNES": One teacher's journey in claiming and embracing her nonnative-speaker identity. TESOL Quarterly, 46(1), 127-152.

Patton, M. Q. (2002). Qualitative research and evaluation methods (3rd ed.). Thousand Oaks, CA: Sage.

Pavlenko, A. (2003). "I never knew I was a bilingual": Reimagining teacher identities in TESOL. Journal of Language, Identity, \& Education, 2(4), 251-268.

Pavlenko, A. (2007). Autobiographic narratives as data in applied linguistics. Applied Linguistics, 28(2), $163-188$.

Pavlenko, A. (2008). Narrative analysis in the study of bi- and multilingualism. In M. Moyer \& L. Wei (Eds.), The Blackwell guide to research methods in bilingualism (pp. 311-325). Oxford, UK: Blackwell.

Phillipson, R. (1992). Linguistic imperialism. UK: Oxford University Press.

Polanyi, L. (1995). Language learning and living abroad: Stories from the field. In B. F. Freed (Ed.), Second language acquisition in a study abroad context (pp. 271-291). Philadelphia, PA: John Benjamins.

Risager, K. (2000). The teacher's intercultural competence. Sprogforum, 18(6), 14-20.

Roberts, C. (2003). Ethnography and cultural practice: Ways of learning during residence abroad. In G. Alred, M. Byram, \& M. Fleming (Eds.), Intercultural experience and education (pp. 114-130). UK: Cromwell Press.

Schecter, S., \& Bayley, R. (2004). Language socialization in theory and practice. International Journal of Qualitative Studies in Education, 17(5), 605-625. 
Seidman, I. (2006). Interviewing as qualitative research: A guide for researchers in education and the social sciences (3rd ed.). USA: Teachers College Press.

Sercu, L. (2006). The foreign language and intercultural competence teacher: The acquisition of a new professional identity. Intercultural Education, 17(1), 55-72.

Talmy, S. (2008). The cultural productions of the ESL student at Tradewinds High: Contingency, multidirectionality, and identity in L2 socialization. Applied Linguistics, 29(4), 619-644.

Tsui, A. (2007). Complexities of identity formation: A narrative inquiry of an EFL teacher. TESOL Quarterly, 41(4), $657-680$.

Varghese, M., Morgan, B., Johnston, B., \& Johnson, K. A. (2005). Theorizing language teacher identity: Three perspectives and beyond. Journal of Language, Identity, \& Education, 4(1), 21-44.

Watson-Gegeo, K. A. (2004). Mind, language, and epistemology: Toward a language socialization paradigm for SLA. Modern Language Journal, 88(3), 331-350.

Willett, J. (1995). Becoming first graders in an L2: An ethnographic study of L2 socialization. TESOL Quarterly, 29(3), 473-503.

Xu, S., \& Connelly, F. M. (2009). Narrative inquiry for teacher education and development: Focus on English as a foreign language in China. Teaching and Teacher Education, 25, 219-227. 